\title{
Persepsi Wisatawan, Pelancong, Dan Masyarakat Lokal Terhadap Sistem Transportasi Umum Di Destinasi Wisata Pantai Kuta
}

I Gede Adi Wika Darmawana, 1, I Putu Anomª, 2

1 gedewikaadi@gmail.com, $\underline{2}$ putuanom@unud.ac.id

a Program Studi S1 Destinasi Pariwisata, Fakultas Pariwisata,Universitas Udayana, Jl. Dr. R. Goris, Denpasar, Bali 80232 Indonesia

\begin{abstract}
Kuta Beach is known as tourist favourite attraction in Bali, it can be seen by the number of tourists visited Kuta Beach. However, the high level of tourists, travelers and local communities to Kuta Beach who use private vehicles create traffic jam at Kuta Beach. In this study aims to determine the perception of tourists, travelers and local communities if the implementation of public transport as a special means to Kuta Beach to reduce congestion caused by private vehicles.

The research methodology used is quantitative method. With the technique of determining the number of samples using random sampling and quota sampling. In collecting the data using techniques study literature, observation, interviews, documentation, and distribution of the questionnaire to the 40 respondents. In a data analysis technique used descriptive qualitative method by utilizing the percentage of data.

The results show the perception of tourists, travelers and local communities towards the implementation of transportation common in Kuta Beach, which answered agree as many as 16 people (40\%) strongly agree 15 people (37.5\%), undecided 5 people (12.5\%), not agree 4 people (10\%), strongly disagree 0 (0\%). Thus the total percentage of the perception of tourists, travelers and local communities can be seen in the implementation of public transport in the Kuta Beach, the majority of local people answered agree but local communities said the hesitation and do not agree that the implementation of the proposal.
\end{abstract}

Keywords : Kuta Beach, Perception, Tourists, Travelers, Local Communities, Public Transportation.

\section{PENDAHULUAN}

Aspek utama destinasi wisata yang memiliki peranan besar dalam keberhasilan suatu kegiatan pariwisata setelah atraksi adalah aksesibilitas. Aksesibilitas harus ada sistem transportasi sebagai pelengkapnya. Sistem transportasi adalah suatu kesatuan yang terdiri atas angkutan muatan (barang) dan manajemen yang mengelola angkutan tersebut (Salim, 1993). Sementara definisi dari transportasi itu sendiri adalah kegiatan pemindahan barang (muatan) dan penumpang dari suatu tempat ke tempat lain. Elemen-elemen dari sebuah sistem pariwisata yang sederhana menyangkut sebuah daerah/negara asal wisatawan, sebuah daerah/negara tujuan wisata dan sebuah tempat transit. Ketiga elemen tersebut tidak akan bergerak tanpa adanya sebuah sistem yang mampu memindahkan wisatawan dari daerah asal ke tempat transit untuk selanjutnya menuju ke daerah/negara tujuan wisata dan terakhir meninggalkan daerah tujuan wisata karena kegiatan pariwisata hanya bersifat temporer/sementara. Sistem transportasi inilah yang membuat wisatawan dapat berpindah dari daerah asal ke tujuan yang diinginkan karena sistem tersebut memungkinkan terjadinya pergerakan dari satu tempat ke tempat lain menurut Leiper dalam Pitana dan Diarta (2009).

Aksesibilitas yang kurang memadai dapat menghambat wisatawan. Aksesibilitas merupakan sarana dan infrastruktur untuk menuju destinasi seperti jalan raya, ketersediaan sarana transportasi dan ramburambu penunjuk jalan. Kementerian Pariwisata masih beranggapan bantuan cukup adanya prasarana jalan sudah dapat menarik pelancong berkunjung. Padahal ada yang tidak dipikirkan dan ini harus dimasukkan dalam Perpres nantinya, yakni sektor transportasi umum yang aman dan nyaman. Jika hanya berfikir jalan raya saja sebagai pendukung kegiatan wisata, maka kurang memadai sebagai contoh kawasan wisata Puncak, Bogor, Jawa Barat. Infrastruktur jalan yang baik, tapi tidak dibarengi dengan penyediaan sarana transportasi umum yang baik dan memadai, hasilnya tidak maksimal bahkan kontraproduktif. Hampir sepanjang jalan lalu lintas macet dan akhirnya memperburuk citra Puncak sebagai kawasan wisata andalan di Jabodetabek. Sebagian besar destinasi wisata di Bali Selatan khususnya sudah memiliki aksesibiltas prasarana jalan yang baik sehingga wisatawan, pelancong maupun masyarakat lokal dapat dengan mudah 
untuk mencapai lokasi destinasi yang hendak dituju. Namun kondisi layanan transportasi umumnya yang masih buruk menyebabkan kemacetan lalu lintas seringkali terjadi ketika musim liburan tiba (beritatrans.com, 2016).

Keberadaan transportasi umum di Bali masih lebih sedikit dibandingkan dengan kendaraan pribadi. Padahal, selain sepeda motor dan mobil pribadi yang digunakan untuk mengangkut penumpang/wisatawan, dapat digunakan pula kendaraan angkutan umum seperti bus dan kendaraan yang disediakan di kawasan Central Parkir Kuta.

Penggunaan angkutan umum akan dapat mengurangi volume kendaraan pribadi yang berlebihan karena dalam satu jenis angkutan umum seperti bus trayek, dokar, taxi akan memuat kuantitas penumpang yang jauh lebih banyak dibandingkan dengan penggunaan kendaraan pribadi seperti sepeda motor dan mobil pribadi. Dari segi penggunaan bahan bakar minyak juga menjadi lebih hemat yang nantinya berdampak pada konsumsi minyak negara. Hanya saja, penerapan pemberlakuan transportasi umum memerlukan pula sistem transportasi darat yang memadai

Pantai Kuta adalah salah satu destinasi andalan Bali yang ketenarannya sudah tidak perlu diragukan lagi hingga ke mancanegara. Hampir setiap wisatawan yang berkunjung ke Bali untuk datang ke Pantai Kuta. Kunjungan wisatawan ke Pantai Kuta pada saat musim liburan sangat ramai dikunjungi wisatawan baik domestik maupun mancanegara. Situasi ini berdampak pada arus lalu lintas di sepanjang jalan di kawasan pantai mengalami kemacetan. Walaupun polisi sudah bertugas untuk mengurai kemacetan di jalan raya Pantai Kuta, namun kemacetan tetap terjadi yang didominasi kendaraan roda empat. Parkir mobil di pinggir jalan raya Pantai Kuta yang kurang teratur dan rentetan pengendara sepeda motor yang hendak parkir ataupun meninggalkan parkiran juga membuat bertambah parahnya kemacetan (bali.tribunnews.com, 2016).

Kondisi kemacetan yang seringkali terjadi di sepanjang jalan Pantai Kuta ini harus mendapat perhatian dan penanganan yang serius dari pemerintah. Apabila dibiarkan terjadi terus menerus, dapat mempengaruhi tingkat kejenuhan dan kenyamanan dalam berwisata yang nantinya bisa berimbas pada citra Pantai Kuta buruk dimata wisatawan.
Oleh sebab itu langkah awal yang dapat dilakukan peneliti sebagai sumbangsih bagi pariwisata di Kuta adalah melakukan penelitian terkait dengan persepsi para wisatawan, pelancong dan masyarakat lokal terhadap penerapan kendaraan angkutan umum sebagai salah satu solusi untuk mengatasi kemacetan yang terjadi akibat banyaknya kendaraan pribadi di kawasan Pantai Kuta.

\section{TINJAUAN PUSTAKA}

Penelitian ini menggunakan beberapa pedoman konsep dan teori untuk menganalisis data yang didapat di lapangan, yaitu:

1. Konsep persepsi menurut Rangkuti (2003) persepsi diidentifikasikan sebagai suatu proses dimana individu memilih mengorganisasikan serta mengartikan stimulus yang diterima melalui inderanya menjadi suatu makna, meskipun demikian makna dari proses persepsi tersebut juga dipengaruhi pengalaman masa lalu individu yang bersangkutan.

2. Konsep wisatawan berdasarkan Undang-Undang Kepariwisataan No 10 Tahun 2009 : orang yang melakukan wisata. Sementara itu arti dari wisata sendiri adalah kegiatan perjalanan yang dilakukan oleh seseorang atau sekelompok orang dengan mengunjungi tempat tertentu untuk tujuan rekreasi, pengembangan pribadi, atau mempelajari keunikan daya tarik wisata yang dikunjungi dalam jangka waktu sementara.

3. Konsep pelancong Menurut Leiper (1981), Pelancong adalah wisatawan domestik yang melakukan perjalanan hanya untuk beristirahat dari rutinitasnya hanya dalam jangka waktu selama kurang lebih satu hari di daerah tujuan mereka.

4. Konsep daya tarik wisata berdasarkan Undang-Undang Kepariwisataan No. 10 Tahun 2009 : segala sesuatu yang memiliki keunikan, keindahan, dan nilai yang berupa keanekaragaman kekayaan alam, budaya, dan hasil buatan manusia yang menjadi sasaran atau tujuan kunjungan wisatawan. 
5. Konsep Masyarakat lokal adalah kesatuan hidup manusia yang berinteraksi menurut suatu sistem adat istiadat tertentu yang bersifat kontinu, dan yang terkait oleh satu rasa identitas bersama. Kontinuitas merupakan kesatuan masyarakat yang memiliki keempat ciri, yaitu: interaksi antara warga-warganya, adat istiadat, kontinuitas waktu, rasa identitas kuat yang mengikat semua warga (Koentjaraningrat, 2011).

6. Konsep transportasi menurut Salim (1993) adalah kegiatan pemindahan barang atau muatan dan penumpang dari suatu tempat ke tempat lain. Dalam transportasi ada dua unsur yang terpenting yaitu pemindahan atau pergerakan dan secara fisik mengubah tempat dari barang atau komoditi dan penumpang ke tempat lain.

\section{METODE}

Penelitian ini dilakukan di daya tarik wisata Pantai Kuta, Desa Adat Kuta, Kabupaten Badung. Adapun ruang lingkup penelitian yang digunakan yaitu :

1. Persepsi wisatawan, pelancong, dan masyarakat lokal terhadap sistem transportasi umum di Pantai Kuta.

2. Sistem transportasi umum untuk menanggulangi kemacetan di Pantai Kuta.

Jenis dan sumber data dalam penelitian ini menggunakan jenis data kualitatif, seperti: hasil wawancara yang ditulis dengan deskriptif seperti informasi gambaran umum daya tarik wisata Pantai Kuta dan sistem transportasi umumnya. jenis data kuantitatif dalam penelitian ini adalah persepsi wisatawan, pelancong, dan masyarakat lokal terhadap sistem transportasi umum di Pantai Kuta. Sumber data yang digunakan yaitu sumber data primer serta sumber data sekunder (Sujarweni, 2013). Dalam pengumpulan data menggunakan empat teknik, yaitu: observasi, wawancara, kuesioner (Sugiyono, 2014) dan metode dokumenter (Bungin, 2007). Teknik penentuan informan dalam penelitian ini menggunakan teknik purposive sampling. Purposive Sampling adalah cara penentuan sejumlah informan sebelum penelitian dilaksanakan, dengan menyebutkan secara jelas siapa yang dijadikan informan serta informasi apa saja yang diinginkan dari masing-masing informan. Sampel dalam penelitian di Pantai Kuta ini adalah wisatawan, pelancong dan masyarakat lokal. Dari ketiga jenis sampel tersebut, nantinya akan ditentukan masingmasing jumlah kuota yang diperlukan secara acak.

Hasil penelitian ini nantinya akan dianalisis dengan metode deskriptif kualitatif Bogdan \& Biklen, (1982) dalam Bungin, (2007) analisis data kualitatif, yaitu upaya yang dilakukan dengan jalan sebagai berikut.

Bekerja dengan data; Mengorganisasikan data; Memilah-milahnya menjadi satuan yang dapat dikelola; Menyintesiskannya; Mencari dan menemukan pola; Menemukan apa yang penting dan apa yang dipelajari; Memutuskan apa yang dapat diceritakan kepada orang lain.

\section{HASIL DAN PEMBAHASAN}

Daerah kuta menjadi daerah tujuan wisata semenjak tahun 1970an. Daya tarik yang dimiliki oleh Kuta adalah keindahan pantai pasir putihnya. Desa adat Kuta berkembang mulai dari tahun 1990 dimulai dengan pembangunan hotel-hotel besar sampai dengan fasilitas lainnya seperti tempat belanja (mall). Pada tahun 2000 Kuta mengalami fluktuasi seperti pada tahun 2002 dan 2004 yang dikenal dengan tragedi Bom Bali. Pada saat tragedi tersebut Pantai Kuta mengalami kemunduran dalam perkembangan pariwisatanya dan juga berdampak besar kepada kepariwisataan Bali pada saat itu.

Pengumpulan data terkait persepsi wisatawan, pelancong, masyarakat lokal terhadap sistem transportasi umum di Pantai Kuta memerlukan beberapa responden dalam mengambil data untuk dianalisis.

Responden yang ditetapkan sebanyak 40 orang responden dan diperoleh karakteristik responden yang diberikan kuesioner yaitu daerah asal responden sebanyak 17 orang responden merupakan warga negara asing, 16 orang responden merupakan warga negara Indonesia dari luar Provinsi Bali, dan 7 orang dari Provinsi Bali. Karakteristik responden berdasarkan jenis kelamin terdiri dari responden laki-laki 
sebanyak 19 orang dan responden perempuan sebanyak 21 orang. Rentan usia dominan responden adalah 17-25 tahun sebanyak 24 responden, rentan usia 26-35 tahun sebanyak 10 responden dan 36-45 tahun sebanyak 6 responden. Pekerjaan responden didominasi oleh swasta dengan jumlah 20 orang responden sementara pelajar sebanyak 8 orang, dan sebagai wiraswasta sebanyak 12 orang.

Berdasarkan hasil dari kuesioner yang telah disebarkan kepada 40 orang responden dapat diketahui bahwa persepsi wisatawan, pelancong, masyarakat lokal terhadap penerapan transportasi umum di kawasan Pantai Kuta dapat dilihat pada tabel-tabel berikut.

Tabel 4.1

Kunjungan ke Pantai Kuta

\begin{tabular}{|l|l|l|}
\hline No & $\begin{array}{l}\text { Wisatawan, } \\
\text { Pelancong dan } \\
\text { Masyarakat Lokal }\end{array}$ & $\begin{array}{l}\text { Jumlah } \\
\text { (Orang) }\end{array}$ \\
\hline 1 & Pertama Kali & 9 \\
\hline 2 & Lebih Dari Sekali & 31 \\
\hline \multicolumn{2}{|c|}{ Total } & 40 \\
\hline
\end{tabular}

Sumber : Hasil Penelitian, 2016

Berdasarkan Tabel 4.1 dapat diketahui bahwa wisatawan, pelancong, dan masyarakat lokal yang mendominasi adalah kunjungan lebih dari sekali berkunjung ke Pantai Kuta sebanyak 31 orang $(77.5 \%)$, sedangkan sebanyak 9 orang $(22.5 \%)$ mengatakan pertama kali berkunjung ke Pantai Kuta. Alasan responden melakukan kunjungan ulang ke Pantai Kuta dikarenakan Pantai Kuta adalah daya tarik wisata yang menarik, beragam aktifitas dapat dilakukan di Pantai Kuta dan juga fasilitas pendukung yang lengkap dan dekat dengan penginapan dari wisatawan tersebut.

Tabel 4.2

Menggunakan Transportasi Umum

\begin{tabular}{|c|c|c|}
\hline No & $\begin{array}{c}\text { Wisatawan, } \\
\text { Pelancong, dan } \\
\text { Masyarakat Lokal }\end{array}$ & $\begin{array}{c}\text { Jumlah } \\
\text { (Orang) }\end{array}$ \\
\hline 1 & Iya & 13 \\
\hline 2 & Tidak & 27 \\
\hline \multicolumn{2}{|c|}{ Total } \\
\hline
\end{tabular}

Sumber : Hasil Penelitian, 2016
Berdasarkan Tabel 4.2 diketahui bahwa wisatawan, pelancong, masyarakat lokal yang menggunakan transportasi umum menuju kawasan Pantai Kuta sebanyak 13 orang dengan persentase sebesar (32.5\%), sedangkang yang tidak menggunakan transportasi umum sebanyak 27 orang dengan persentase sebesar (67.5\%). Alasan responden lebih banyak menggunakan transportasi pribadi dari pada transportasi umum dikarenakan transportasi pribadi lebih efisien dalam waktu dan ekonomi menuju kawasan Pantai Kuta.

Tabel 4.3

Jenis Kendaraan yang Digunakan

\begin{tabular}{|c|c|c|}
\hline No & $\begin{array}{l}\text { Wisatawan, } \\
\text { Pelancong dan } \\
\text { Masyarakat Lokal }\end{array}$ & $\begin{array}{l}\text { Jumlah } \\
\text { (Orang) }\end{array}$ \\
\hline 1 & $\begin{array}{c}\text { Tidak Menggunakan } \\
\text { Kendaraan }\end{array}$ & 8 \\
\hline 2 & Sepeda Motor & 25 \\
\hline 3 & Sepeda Gayung & 1 \\
\hline 4 & Mobil & 6 \\
\hline Total & & 40 \\
\hline
\end{tabular}

Sumber : Hasil Penelitian, 2016

Berdasarkan Tabel 4.3 diketahui bahwa wisatawan, pelancong, dan masyarakat lokal yang menggunakan sepeda motor sebanyak 25 orang dengan persentase sebesar (62.5\%), sedangkan responden yang tidak memilih menggunakan kendaraan sebanyak 8 orang dengan besar persentase sebanyak (20\%), sedangkan responden yang memilih kendaraan mobil sebanyak 6 orang dengan persentase sebesar (15\%), dan responden yan memilih sepeda gayung sebanyak 1 orang dengan persentase sebesar (2.5\%). Alasan dari responden lebih menggunakan sepeda motor sebagai transportasi pribadi dikarenakan sepeda motor lebih efisien digunakan menuju kawasan Pantai Kuta yang padat.

Dari hasil analisis diatas dapat ditarik kesimpulan persepsi wisatawan, pelancong, dan masyarakat lokal dalam penerapan transportasi umum di Pantai Kuta didominasi tipe responden kunjungan beulang atau berkunjung lebih dari sekali ke Pantai Kuta karena kelengkapan aktifitas dan fasilitas serta lokasinya dekat dengan penginapan. Responden dominan menggunakan transportasi pribadi sepeda motor dibandingkan transportasi umum dikarenakan masalah efisiensi jarak dan waktu 
tempuh jika dibandingkan dengan menggunakan kendaraan roda empat.

\subsubsection{Persepsi Wisatawan, Pelancong dan Masyarakat Lokal Terhadap Sistem Transportasi Umum di Pantai Kuta}

Untuk mengetahui Kondisi kemacetan yang terjadi di kawasan Pantai Kuta, maka kepada wisatawan, pelancong dan masyarakat lokal yang berkunjung ke kawasan daya tarik Pantai Kuta diberikan kuesioner. Hasil jawaban yang diberikan oleh keseluruhan reponden serta persentasenya dapat dilihat pada tabel-tabel berikut.

Tabel 4.4

Apakah Anda Mengalami Kemacetan Saat Berwisata ke Pantai Kuta

\begin{tabular}{|l|l|l|}
\hline No & $\begin{array}{l}\text { Wisatawan, } \\
\text { Pelancong dan } \\
\text { Masyarakat Lokal }\end{array}$ & $\begin{array}{l}\text { Jumlah } \\
\text { (Orang) }\end{array}$ \\
\hline 1 & Iya & 37 \\
\hline 2 & Tidak & 3 \\
\hline \multicolumn{2}{|l|}{ Total } & 40 \\
\hline
\end{tabular}

Sumber : Hasil Penelitian, 2016

Berdasarkan Tabel 4.4 diketahui bahwa wisatawan, pelancong, dan masyarakat mengalami kemacetan lalu lintas di kawasan Pantai Kuta yaitu sebanyak 37 orang dengan persentase sebesar (92.5\%), sedangkan responden yang menjawab tidak sebanyak 3 orang denga persentase sebesar (7.5\%). Hal tersebut dikarenakan kemacetan di Pantai Kuta sudah menjadi permasalahan yang telah lama terjadi di kawasan Pantai Kuta. Kondisi kemacetan di Pantai Kuta dikarenakan pertumbuhan kendaraan yang menuju ke Pantai Kuta tidak diimbangi oleh pengadaan jalan yang memadai. Kondisi ini diperparah dengan angkutan umum seperti taxi yang berhenti sembarangan di tengah jalan sehingga mengakibatkan kemacetan.

Tabel 4.5

Apakah Kemacetan Mengganggu Anda

\begin{tabular}{|l|l|l|}
\hline No & $\begin{array}{l}\text { Persepsi Wisatawan, } \\
\text { Pelancong dan } \\
\text { Masyarakat Lokal }\end{array}$ & $\begin{array}{l}\text { Jumlah } \\
\text { (Orang) }\end{array}$ \\
\hline 1 & Iya & 34 \\
\hline 2 & Tidak & 6 \\
\hline \multicolumn{2}{|l|}{ Total } & 40 \\
\hline
\end{tabular}

Sumber : Hasil Penelitian, 2016
Berdasarkan Tabel 4.5 diketahui persepsi wisatawan, pelancong, dan masyarakat lokal dominan merasa terganggu dengan kemacetan di Pantai Kuta yaitu sebanyak sebanyak 34 orang responden dengan persentase sebesar (85\%), sedangkan responden yang merasa tidak terganggu dengan kemacetan di Pantai Kuta sebanyak 6 orang dengan persentase sebesar (15\%). Responden yang merasa terganggu selama berkunjung ke kawasan Pantai Kuta karena kondisi kemacetan, beranggapan bahwa kemacetan tersebut membuang waktu yang dimiliki serta menimbulkan polusi sehingga membuat keadaan tidak nyaman bagi responden.

Berdasarkan hasil analisis tersebut ditarik kesimpulan bahwa dominan responden mengalami kemacetan saat berwisata ke Pantai Kuta dikarenakan pertumbuhan mobilisasi kendaraan yang tinggi ke Pantai Kuta dan responden merasa terganggu dengan kemacetan dikarenakan membuang waktu yang mereka miliki serta menimbulkan polusi.

\subsubsection{Faktor Penyebab Kemacetan pada Pantai Kuta}

Faktor-Faktor penyebab terjadinya kemacetam di kawasan Pantai Kuta dapat dilihat pada Tabel 4.6, 4.7, dan 4.8.

Tabel 4.6

Apakah Pengguna Jalan Sudah Tertib

\begin{tabular}{|l|l|l|}
\hline No & $\begin{array}{l}\text { Persepsi Wisatawan, } \\
\text { Pelancong dan } \\
\text { Masyarakat Lokal }\end{array}$ & $\begin{array}{l}\text { Jumlah } \\
\text { (Orang) }\end{array}$ \\
\hline 1 & Tertib & 10 \\
\hline 2 & Tidak Tertib & 22 \\
\hline 3 & Biasa Saja & 8 \\
\hline \multicolumn{2}{|l|}{ Total } & 40 \\
\hline
\end{tabular}

Sumber : Hasil Penelitian, 2016

Berdasarkan Tabel 4.6 diketahui bahwa persepsi dari wisatawan, pelancong dan masyarakat lokal mengenai para pengguna jalan didominasi oleh persepsi yang menyatakan bahwa pengguna jalan tidak tertib sebanyak 22 orang dengan persentase sebesar (55\%), yang tertib dan mentaati rambu-rambu lalu lintas sebanyak 10 orang dengan persentase sebesar (25\%), Responden dominan menjawab, para pengguna jalan tidak tertib dan tidak mentaati rambu-rambu lalu lintas dikarenakan pengguna jalan tersebut 
cenderung tidak sadar melakukan pelanggaran sehingga menimbulkan kemacetan. Pelanggaran yang dilakukan seperti angkutan umum yang berhenti ditengah jalan, parkir di tempat yang tidak seharusnya, menyebrang jalan di tempat yang tidak seharusnya.

Tabel 4.7

Apakah Juru Parkir dan Polisi Pariwisata Bertugas Dengan Baik

\begin{tabular}{|c|c|c|}
\hline No & $\begin{array}{l}\text { Persepsi } \\
\text { Wisatawan, } \\
\text { Pelancong, dan } \\
\text { Masyarakat Lokal }\end{array}$ & $\begin{array}{l}\text { Jumlah } \\
\text { (Orang) }\end{array}$ \\
\hline 1 & Baik & 16 \\
\hline 2 & cukup & 10 \\
\hline 3 & Tidak Baik & 14 \\
\hline \multicolumn{2}{|c|}{ Total } & 40 \\
\hline
\end{tabular}

Sumber : Hasil Penelitian, 2016

Tabel 4.7 menunjukan bahwa persepsi wisatawan, pelancong dan masyarakat lokal mengenai peran petugas juru parkir dan polisi pariwisata yang bertugas di Pantai Kuta. Sebanyak 16 orang menjawab baik atau dengan persentase sebesar (40\%), sedangkan 10 orang menjawab cukup dengan persentase sebesar (25\%), dan sisanya 14 orang menjawab kurang dengan persentase sebesar (35\%). Perbedaan yang tidak terlalu besar antara responden yang menjawab baik dengan responden yang menjawab buruk dikarenakan juru parkir dan polisi pariwisata tidak selalu dapat membantu mengurai kemacetan. Polisi pariwisata dan juru parkir memiliki jobdesk lainnya masing-masing yang harus dilakukan sehingga masalah kemacetan dikesampingkan sementara.

Tabel 4.8

Apakah Lokasi dan Penaataan Parkir Sudah Memadai

\begin{tabular}{|l|l|l|}
\hline No & $\begin{array}{l}\text { Persepsi Wisatawan, } \\
\text { Pelancong dan } \\
\text { Masyarakat Lokal }\end{array}$ & $\begin{array}{l}\text { Jumlah } \\
\text { (Orang) }\end{array}$ \\
\hline 1 & Memadai & 11 \\
\hline 2 & Cukup & 17 \\
\hline 3 & Tidak Memadai & 12 \\
\hline \multicolumn{2}{|l|}{ Total } & 40 \\
\hline
\end{tabular}

Sumber : Hasil Penelitian, 2016

Berdasarkan Tabel 4.8 diketahui bahwa persepsi wisatawan, pelancong, dan masyarakat lokal mengenai lokasi dan penataan parkir di Pantai Kuta sebanyak 17 orang menjawab cukup dengan persentase sebesar (42.5\%), sedangkan responden yang menjawab tidak memadai sebanyak 12 orang dengan persentase sebesar (30\%), dan sisanya sebanyak 11 orang menjawab memadai dengan persentase sebesar (27.5\%). Dominannya responden yang menjawab lokasi dan penataan parkir cukup memadai dikarenakan keadaan area parkir yang didominasi untuk kendaraan beroda dua sementara untuk kendaraan beroda empat tidak memiliki tempat parkir yang cukup memadai.

\subsubsection{Persepsi Penerapan Transportasi Umum pada Pantai Kuta}

Berdasarkan hasil dari kuesioner yang sudah disebarkan kepada 40 responden, maka dapat diketahui hasil dari analisis kuesioner tentang persepsi wisatawan, pelancong, masyarakat lokal terhadap sistem transportasi umum di kawasan Pantai Kuta. Hasil kuesioner yang diberikan kepada seluruh responden dapat dilihat pada Tabel 4.9 dan 4.10.

Tabel 4.9

Persepsi Jika Diterapkan Transportasi Umum

\begin{tabular}{|l|l|l|}
\hline No & $\begin{array}{l}\text { Persepsi Wisatawan, } \\
\text { Pelancong dan } \\
\text { Masyarakat Lokal }\end{array}$ & $\begin{array}{l}\text { Jumlah } \\
\text { (Orang) }\end{array}$ \\
\hline 1 & Sangat Setuju & 15 \\
\hline 2 & Setuju & 16 \\
\hline 3 & Ragu-Ragu & 5 \\
\hline 4 & Tidak Setuju & 4 \\
\hline 5 & Sangat Tidak Setuju & 0 \\
\hline \multicolumn{2}{|l|}{ Total } & 40 \\
\hline
\end{tabular}

Sumber : Hasil Penelitian, 2016

Berdasarkan Tabel 4.9 diketahui bahwa persepsi wisatawan, pelancong, dan masyarakat lokal mengenai diterapkannya transportasi umum untuk mengatasi kemacetan di kawasan Pantai Kuta sebagai pengganti kendaraan pribadi, sebanyak 16 orang menjawab setuju dengan persentase sebesar (40\%), sedangkan sebanyak 15 orang menjawab sangat setuju dengan persentase sebesar $(37.5 \%)$, sebanyak 5 orang menjawab ragu-ragu dengan persentase sebesar $(12.5 \%)$, dan sisanya sebanyak 4 orang menjawab tidak setuju dengan persentase sebesar (10\%).

Responden dominan menyatakan kesetujuannya terhadap penerapan 
transportasi umum untuk mengatasi kemacetan di kawasan Pantai Kuta. Hal tersebut dikarenakan dengan berkurangnya transportasi pribadi yang selama ini digunakan wisatawan dan pelancong untuk berkunjung ke Pantai Kuta dapat mengurangi kemacetan lalu lintas yang terjadi. Sehingga selain masyarakat lokal, wisatawan dan pelancong yang berkunjung ke Pantai Kuta sebaiknya menggunakan moda transportasi umum untuk mengurangi kemacetan.

Tabel 4.10

Apa Anda Akan Berkunjung Kembali ke Pantai Kuta

\begin{tabular}{|l|l|l|}
\hline No & $\begin{array}{l}\text { Persepsi Wisatawan, } \\
\text { Pelancong dan } \\
\text { Masyarakat Lokal }\end{array}$ & $\begin{array}{l}\text { Jumlah } \\
\text { (Orang) }\end{array}$ \\
\hline 1 & Iya & 35 \\
\hline 2 & Tidak & 0 \\
\hline 3 & Pikir-Pikir & 5 \\
\hline \multicolumn{2}{|l|}{ Total } & 40 \\
\hline
\end{tabular}

Sumber : Hasil Penelitian, 2016

Berdasarkan Tabel 4.10 diketahui bahwa persepsi wisatawan, pelancong, dan masyarakat lokal mengenai kunjungan kembali atau tidaknya responden ke Pantai Kuta dapat dilihat dari, sebanyak 35 orang menjawab ya akan berkunjung kembali ke Pantai Kuta dengan persentase sebesar (87.5\%), sedangkan yang menjawab pikir-pikir untuk berkunjung kembali ke Pantai Kuta sebanyak 5 orang dengan persentase sebesar (12.5\%). Pantai Kuta sudah menjadi daya tarik wisata favorit di Bali. Nama besar Pantai Kuta menjadi prestise tersendiri bagi siapapun yang berkunjung. Lengkapnya atraksi dan fasilitas yang ditawarkan membuat pengunjungnya rela menghabiskan waktu lama saat berkunjung ke Pantai Kuta.

Berdasarkan analisis tersebut dapat ditarik kesimpulan bahwa dominan responden menyatakan setuju apabila diterapkannya transportasi umum sebagai sarana menuju kawasan Pantai Kuta bagi wisatawan dan pelancong. Dari tingkat berkunjung responden lebih banyak menjawab untuk berkunjung kembali ke Pantai Kuta karena daya tarik Pantai Kuta memiliki prestise tersendiri dan lengkapnya aktifitas dan fasilitas yang ditawarkan.

\subsection{Sistem Transportasi umum untuk mengurangi kemacetan di Pantai Kuta}

Sistem tranportasi umum untuk mengurangi kemacetan di Pantai Kuta sebenarnya telah lama dipikirkan untuk mengurangi kemacetan salah satunya adalah dengan pembuatan Central Parkir sebagai area parkir bagi kendaraan besar seperti bus yang akan memasuki kawasan Kuta.

Sejarah Central Parkir dimulai dari Komutra Transport yang dahulu bernama Komitra. Central Parkir didirikan pada tanggal 6 Mei 1999. Latar belakang didirikannya Central Parkir di Kuta adalah untuk mengurangi kemacetan yang disebabkan oleh kendaraan besar seperti bus, yang parkir pada sejumlah tempat tujuan wisata di Kuta.

Menurut penuturan dari Anwar Tahir selaku pengelola Komutra saat ditemui di kantor Komutra, menjelaskan :

"Bus besar tersebut tidak dapat langsung ke Pantai Kuta namun harus transit terlebih dahulu di Central Parkir dan menyewa suttel bus. Sistem operasionalnya, bus besar turun di Cetral Parkir lalu dari Central Parkir mengantar ke berbagai tempat dan tergantung dari tempat tujuan yang diinginkan wisatawan seperti ke hotel, ke mall, atau ke pantai. Namun rute yang paling diminati oleh wisatawan yang datang berkunjung dan transit di Central Parkir adalah ke Pantai Kuta. Wisatawan tersebut akan di drop langsung di depan Hard Rock Cafe atau di depan Pantai Kuta setelah itu wisatawan bebas melakukan kegiatan apapun tanpa ada waktu yang dibatasi. Jika wisatawan sudah cukup untuk melakukan kegiatan di pantai kuta maka tour leader dari wisatawan tersebut akan menghubungi petugas kordinator lapangan di Central Parkir untuk menjemput wisatawan di Pantai Kuta." (Sumber wawancara 17/05/2016).

Berdasarkan pemaparan tersebut dapat disimpulkan bahwa pihak Central Parkir sudah melakukan usahanya untuk mengurai kemacetan yang dapat timbul dengan mewajibkan kendaraan besar untuk menurunkan wisatawan di Central Parkir dan perjalanan dilanjutkan dengan suttel bus yang lebih kecil. Hal tersebut diharapkan dapat menanggulangi kemacetan yang terjadi. Kebijakan tersebut sangat beralasan, melihat dari tidak tersedianya lahan parkir bagi bus-bus besar dan juga kondisi jalan yang tidak terlalu lebar sehingga hanya dengan satu buah bus 
besar dapat menganggu kondisi lalu lintas dan menciptakan kemacetan, tidak hanya pada saat bus berjalan saja, namun juga saat bus akan parkir dan berbelok arah karena luasnya haluan yang harus diambil sedangkan jalan yang tersedia tidak begitu besar.

Tidak hanya bus besar, kendaraan roda empat seperti taxi saja dapat membuat kemacetan ketika mengangkut dan menurunkan penumpangnya. Hal tersebut dikarenakan lalu lintas di Pantai Kuta adalah jalur dua arah dengan kondisi lalu lintas yang cukup padat. Dengan disediakannya angkutan masal yang lebih kecil dan fleksibel diharapkan dapat mengurangi potensi kemacetan yang terjadi di daerah Kuta. Komutra Central Parkir memiliki 35 Suttel Bus dan Kurang lebih 40 sopir, sehingga untuk satu buah suttle bus dapat diisi dengan dua orang sopir. Namun mulai muncul permasalahan seperti persaingan dengan transportasi umum lainnya. Komutra siap membantu dan memberikan ijin kepada sopirnya untuk mengangkut penumpang yang ingin melakukan kegiatan perjalanan di luar area Kuta, seperti melakukan kegiatan persembahyangan ke Besakih, dan acara pernikahan.

Komutra Transport di Central Parkir bekerjasama bersama dengan guide untuk mencari wisatawan dengan harga yang ditawarkan untuk sekali berangkat Rp 70.000 jika pulang pergi (PP) Rp 140.000. Kendala dalam operasional Komutra ini terjadi pada saat high season, yaitu pada saat tingginya pertumbuhan wisatawan yang berkunjung, padatnya arus lalu lintas dan kondisi jalan yang sempit membuat transportasi Komutra lebih kewalahan dalam melayani wisatawan. Sehingga membuat perjalanan ke Pantai Kuta yang umumnya dapat di tempuh dalam waktu 10 menit dapat menjadi 1 jam perjalanan.

\section{SIMPULAN DAN SARAN}

\subsection{Simpulan}

Berdasarkan hasil analisis yang dilakukan dapat di tarik kesimpulan sebagai berikut:

1. Wisatawan, pelancong dan masyarakat lokal sebagai responden lebih banyak menggunakan transportasi pribadi seperti sepeda motor. Responden merasakan kemacetan dan kemacetan tersebut mengganggu kenyamanan karena menghabiskan waktu dan juga menimbulkan polusi.

2. Penyebab dominan kemacetan di Pantai Kuta adalah ketidaktaan akan peraturan lalu lintas. Disamping itu lahan parkir yang disediakaan dan optimalisasi peran polisi pariwisata dan petugas parkir masih perlu ditingkatkan untuk dapat memadai kebutuhan wisatawan, pelancong dan masyarakat lokal.

3. Wisatawan, pelancong, dan masyarakat lokal mengatakan setuju apabila diterapkan transportasi umum bagi wisatawan dan pelancong agar dapat mengurangi kendaraan pribadi yang selama ini menjadi penyebab kemacetan.

4. Penerapan sistem transportasi umum di kawasan Kuta sebenarnya sudah ada sejak lama. Komutra mampu menjadi moda transportasi umum yang fleksibel sebagai solusi untuk mengatasi kemacetan. Namun karena ketatnya persaingan dan tingginya arus kendaraan pribadi yang menuju ke kawasan Kuta membuat kemacetan tidak dapat dihindarkan.

\subsection{Saran}

Adapun saran yang dapat diberikan diantaranya adalah :

1. Bagi Pemerintah agar memperhatikan dan memperbaiki fasilitas umum, mengingat akses jalan umum di Pantai Kuta belum memadai dalam menunjang pariwisata dan ditambahkannya tanda jalan di larang berhenti di setiap titik-titik rawan kemacetan.

2. Bagi pengelola Central Parkir lebih baik mengajukan pendapat dalam penerapan transportasi umum ini kepada bendesa adat setempat dan lebih dipersiapkan lagi kualitas dari kendaraan dan sumber daya manusianya.

3. Bagi wisatawan, pelancong dan masyarakat lokal yang berkunjung ke Pantai Kuta dianjurkan untuk mentaati peraturan dan rambu-rambu lalu lintas agar tidak menimbulkan kemacetan. 
Vol. 6 No 1, 2018

\section{DAFTAR PUSTAKA}

Anonim 2009. Undang-Undang No.10 Tahun 2009 Tentang Kepariwisataan

Bungin, 2007. Penelitian Kualitatif. Jakarta: Prenada Media Grup.

Koentjaraningrat. 2011. Pengantar Antropologi I. Jakarta: Rineka Cipta.

Leiper, N. 1981. Towards a Cehonsive Curriculum in Tourism: The Case For a District Discipline. Annals of Tourism Research 8:69-83.

Moh. Nazir Ph.D, 2005. Metode Penelitian. Bogor : Ghalia Indonesia.

Pitana dan Surya Diarta, 2009. Pengantar Ilmu Pariwisata. Yogyakarta: ANDI Yogyakarta.

Rangkuti, Freddy. 2003. Analisis SWOT Teknik Membedah Kasus Bisnis. Jakarta: PT. Gramedia pustaka utama.

Salim, Abbas 1993. Manajemen Transportasi. Jakarta: PT. RajaGrafindo Persada

Sugiono, 2014. Cetakan ke-14. Metode Penelitian Kuantitatif, Kualitatif dan R\&D. Bandung: ALFABETA,CV.

Sujarweni, Wiratna. 2013. Metode Penelitian. Yogjakarta: Pustaka Baru Press

Sumber Lain:

http://beritatrans.com/2016/01/19/sering-macet-lalulintas-di-kuta-diubah-satu-arah/

http://bali.tribunnews.com/2016/05/07/bali-macet-ahsudah-klasik-ini-fakta-faktanya 